\title{
Fine-root trait plasticity of beech (Fagus sylvatica) and spruce (Picea abies) forests on two contrasting soils
}

\author{
Monique Weemstra (D) Frank J. Sterck • \\ Eric J. W. Visser • Thomas W. Kuyper • \\ Leo Goudzwaard • Liesje Mommer
}

Received: 19 May 2016 / Accepted: 8 December 2016 / Published online: 24 December 2016

(C) The Author(s) 2016. This article is published with open access at Springerlink.com

\begin{abstract}
Aim The fine roots of trees may show plastic responses to their resource environment. Several, contrasting hypotheses exist on this plasticity, but empirical evidence for these hypotheses is scattered. This study aims to enhance our understanding of tree root plasticity by examining intra-specific variation in fine-root mass and morphology, fine-root growth and decomposition, and associated mycorrhizal interactions in beech (Fagus sylvatica L.) and spruce (Picea abies (L.) Karst.) forests on soils that differ in resource availability.
\end{abstract}

Responsible Editor: Alain Pierret.

Electronic supplementary material The online version of this article (doi:10.1007/s11104-016-3148-y) contains supplementary material, which is available to authorized users.

M. Weemstra $(\bowtie) \cdot$ F. J. Sterck $\cdot$ L. Goudzwaard Forest Ecology and Forest Management Group, Wageningen University, P.O. Box 47, 6700 AA Wageningen, the Netherlands e-mail: monique.weemstra@wur.nl

M. Weemstra $\cdot$ L. Mommer

Plant Ecology and Nature Conservation Group, Wageningen

University, P.O. Box 47, 6700 AA Wageningen, the Netherlands

E. J. W. Visser

Department of Experimental Plant Ecology, Institute for Water and Wetland Research, Radboud University Nijmegen, P.O. Box 9100, 6500 GL Nijmegen, the Netherlands

\section{T. W. Kuyper}

Department of Soil Quality, Wageningen University, P.O. Box 47, 6700 AA Wageningen, the Netherlands
Methods We measured the mass and morphological traits of fine roots (i.e. $\leq 2 \mathrm{~mm}$ diameter) sampled to $50 \mathrm{~cm}$ depth. Fine-root growth was measured with ingrowth cores, and fine-root decomposition with litter bags. Mycorrhizal fungal biomass was determined using ingrowth mesh bags.

Results Both tree species showed more than three times higher fine-root mass, and a ten-fold higher fine-root growth rate on sand than on clay, but no or marginal differences in overall fine-root morphology. Within the fine-root category however, beech stands had relatively more root length of their finest roots on clay than on sand. In the spruce stands, ectomycorrhizal mycelium biomass was larger on sand than on clay.

Conclusions In temperate beech and spruce forests, fine-root mass and mycorrhizal fungal biomass, rather than fine-root morphology, are changed to ensure uptake under different soil resource conditions. Yet enhancing our mechanistic understanding of fine-root trait plasticity and how it affects tree growth requires more attention to fine-root dynamics, the functional diversity within the fine-roots, and mycorrhizal symbiosis as an important belowground uptake strategy.

Keywords Fagus sylvatica Ectomycorrhizal fungi · Picea abies $\cdot$ Plasticity $\cdot$ Root functional traits

\section{Introduction}

The expression of plant functional traits can be adjusted to the environment, allowing plants of the 
same species to grow and survive under various environmental conditions (Bradshaw 1965; Valladares et al. 2007). Such intra-specific plastic responses to resource availability have been widely observed on leaves (e.g. Ryser and Eek 2000; Poorter et al. 2012; Sterck et al. 2013), but are far less studied on roots (Bardgett et al. 2014), especially of mature trees growing in forest environments (but see e.g., Ostonen et al. 1999; Leuschner et al. 2004; ValverdeBarrantes et al. 2007; Hertel et al. 2013). Plastic responses of fine-roots (i.e. $\leq 2 \mathrm{~mm}$ diameter) can be observed within different fine-root trait categories, being architectural, morphological, chemical and biotic traits (sensu Bardgett et al. 2014). Here, we focus on fine-root architectural traits that describe the spatial arrangement of the root system as a whole (e.g. fine-root mass and length over depth); fine-root morphological traits that represent properties at the individual-root level (e.g. fine-root diameter, specific root length (SRL), and fine-root tissue density (RTD)); and their relation with biotic traits (e.g. mycorrhizal abundance).

Fine-root architectural traits are hypothesized to change with the availability of soil resources (water and nutrients), following the functional equilibrium hypothesis (Brouwer 1963). This hypothesis predicts that fine-root mass increases relative to total plant biomass when soil resources are limiting. However, some studies have confirmed this hypothesis (Yuan and Chen 2010; Hertel et al. 2013), while others have not (Leuschner and Hertel 2003; Finér et al. 2007; Meier and Leuschner 2008). Also, different drivers may underlie such architectural responses; a high fine-root biomass can be achieved by rapid fine-root growth, but also by low fine-root turnover rates, or both. These underlying drivers of fine-root biomass are however difficult to quantify in forest environments (but see e.g. Withington et al. 2006; Gaul et al. 2008; McCormack et al. 2012).

Fine-root morphological traits may also respond to soil resource availability. On the one hand, following the resource economics hypothesis (Grime 1977; Craine 2009), poor soils select for species with thick fine-roots that live long, so that valuable plant resources are conserved (Eissenstat and Yanai 1997; Aerts and Chapin 2000; Wahl and Ryser 2000; Pérez-Ramos et al. 2012; Reich 2014); such relationships between fine-root traits and the soil environment might also exist within species. A contrasting hypothesis, however, predicts thinner fine-roots on poor soils, because these roots grow fast and can more efficiently exploit the soil for resources (Eissenstat 1992; Ryser and Lambers 1995; Eissenstat and Yanai 1997; Ostonen et al. 2007b; Holdaway et al. 2011; Prieto et al. 2015). Both hypotheses have been corroborated and refuted with empirical data (e.g. Fahey and Hughes 1994; Leuschner et al. 2004; Ostonen et al. 2007a, b; Hertel et al. 2013).

The extent to which these different fine-root trait categories are plastic in relation to each other, is currently subject of debate. On the one hand, it has been suggested that fine-root morphological traits are more plastic than architectural traits (Poorter et al. 2012), but other studies have demonstrated the opposite (Ostonen et al. 2007a; Hertel et al. 2013; Freschet et al. 2015). Furthermore, both fine-root architectural and morphological traits may vary as a consequence of interactions with soil biota, such as ectomycorrhizal fungi, which may confound plastic root responses to resource availability (Freschet et al. 2015). On poor soils for example, ectomycorrhizal mycelium biomass increases (Nilsson et al. 2005; Kjøller et al. 2012; Bahr et al. 2013), which enlarges the soil volume available to the plant (Smith and Read 2008), and therefore possibly reduces the need for fine-root architectural or morphological adjustments.

Because of these complex interactions between various fine-root traits and soil biota, understanding fineroot trait plasticity requires studying root dynamics (e.g. root growth), as well as mycorrhizal interactions. Therefore, we studied the plasticity of several fine-root architectural and morphological traits, fine-root growth and decomposition, and mycorrhizal fungal biomass in forests on two soils of different resource availability. We hypothesized that-within a species-forests on resource-poor soils are characterized by 1) greater (relative) fine-root mass and length density, 2) faster fine-root growth and/or slower decomposition to achieve such a high fine-root mass, 3) higher SRL and lower RTD and fine-root diameter, and 4) larger mycorrhizal fungal biomass, compared to forests on resourcerich soils. We tested these hypotheses by comparing fine-root traits of two temperate ectomycorrhizal tree species (European beech (Fagus sylvatica L.) and Norway spruce (Picea abies (L.) Karst.)) growing in forests on contrasting soils, i.e. a resource-poor, sandy soil, and a resource-rich clay soil, in the Netherlands. 


\section{Methods}

Study sites and design

To assess fine-root plastic responses to soil conditions, we selected forest stands on a clay and on a sandy soil located in the centre of the Netherlands. These forests are subjected to similar climate conditions, i.e. a temperate maritime climate with mild winters and summers, and an annual precipitation of approximately $800 \mathrm{~mm}$ (KNMI 2009). The clay and sandy soils largely differ in resource availability (Table 1; Supplementary online Table S1, Fig. S1). The sandy soils had lower $\mathrm{pH}$, lower $\mathrm{CEC}$, higher $\mathrm{C}$ : $\mathrm{N}$ ratios of soil organic matter, and a lower ratio of nitrate over ammonium. Furthermore, plant available water was lower, and groundwater levels were generally deeper at the sandy soils (Table 1; see Supplementary Table S1 for a description of the soil sampling and analyses). For these reasons, we refer to the sandy soil as resource-poor, and the clay soil as resource-rich (Högberg et al. 2003).
On these contrasting soils, we compared fine-root traits of two common temperate tree species: European beech and Norway spruce. At each of the two soil types, we selected three monospecific stands per species. We aimed to minimize age effects by selecting even-aged stands, but could not avoid some age differences (Table 1), although all stands had a closed canopy. Fine-root architectural and morphological data were collected on roots sampled randomly throughout each stand. Data on fine-root growth and decomposition and mycorrhizal fungal biomass were gathered by conducting experiments at six selected dominant trees randomly distributed within each stand in order to maintain a fixed distance between our experiments and the base of a tree stem.

Fine-root architectural and morphological traits

We collected eight soil samples randomly distributed throughout each stand in August 2013, using a $42 \mathrm{~mm}$ root auger. We sampled up to $50 \mathrm{~cm}$ depth and separated

Table 1 Mean stand and soil variables per species and soil type (standard deviation between brackets)

\begin{tabular}{|c|c|c|c|c|}
\hline \multirow{2}{*}{$\begin{array}{l}\text { Species } \\
\text { Soil type }\end{array}$} & \multicolumn{2}{|l|}{ Beech } & \multicolumn{2}{|l|}{ Spruce } \\
\hline & Clay & Sand & Clay & Sand \\
\hline \multicolumn{5}{|l|}{ Stand properties } \\
\hline Year of establishment & $\sim 1970 \mathrm{~s}$ & 1938-1949 & $\sim 1970 \mathrm{~s}$ & $1974-1981$ \\
\hline Stand density (trees ha ${ }^{-1}$ ) & $1071(92.0)$ & $224(36.6)$ & $917(438.6)$ & $1553(446.8)$ \\
\hline Basal area $\left(\mathrm{m}^{2} \mathrm{ha}^{-1}\right)$ & $37.1(4.3)$ & $21.8(4.1)$ & $43.3(11.4)$ & $28.2(3.6)$ \\
\hline Mean DBH (cm) & $19.6(1.6)$ & $34.6(6.3)$ & $24.6(3.5)$ & $14.5(1.1)$ \\
\hline Mean dominant height (m) & $25.0(1.4)$ & $25.8(1.5)$ & $22.5(1.2)$ & $17.5(1.7)$ \\
\hline Top soil fine-root mass $\left(\mathrm{g} \mathrm{m}^{-2}\right)$ & $55.5(39)$ & $322.1(113)$ & $158.6(62)$ & $684.0(181)$ \\
\hline \multicolumn{5}{|l|}{ Soil properties } \\
\hline Soil pH (-) & $6.8(2.0)$ & $3.4(0.9)$ & $6.6(2.1)$ & $3.4(0.9)$ \\
\hline Soil $\mathrm{C}: \mathrm{N}$ ratio $(-)$ & $11.5(3.6)$ & $14.5(6.3)$ & $11.3(2.7)$ & $14.9(6.2)$ \\
\hline Soil organic matter content $(\%)$ & $6.6(1.8)$ & $9.7(11.4)$ & $8.3(4.2)$ & $10.4(14.1)$ \\
\hline Soil N-NO ${ }_{3}^{-}\left(\mathrm{mg} \mathrm{kg}^{-1}\right)$ & $9.0(5.4)$ & $1.0(1.7)$ & $10.1(5.4)$ & $1.7(3.6)$ \\
\hline Soil N-NH${ }_{4}^{+}\left(\mathrm{mg} \mathrm{kg}^{-1}\right)$ & $5.8(6.9)$ & $12.7(12.6)$ & $4.6(2.9)$ & $17.6(13.3)$ \\
\hline Soil P-P $\mathrm{O}_{5}\left(\mathrm{mg} \mathrm{kg}^{-1}\right)$ & $0.5(0.3)$ & $1.2(2.2)$ & $0.5(0.4)$ & $0.6(1.2)$ \\
\hline Plant available water (mm) & $239.8(33.0)$ & $126.0(23.6)$ & $141.1(42.1)$ & $122.6(9.4)$ \\
\hline Groundwater level $^{\mathrm{a}}$ ( $\mathrm{m}$ below soil surface, range) & $0.7-1.9$ & $16-22$ & $0.7-1.9$ & $14-32(0.3-2.4)$ \\
\hline
\end{tabular}

Top soil root mass represents the root mass in the top $10 \mathrm{~cm}$ of the soil. Soil variables are represented by the weighted mean over three soil layers: $0-5,10-20,30-40 \mathrm{~cm}$ soil depth (their data collection methods and depth distribution are presented in Fig. S1). DBH, diameter at breast height; dominant height, mean height of six dominant trees per plot; $\mathrm{C}$, carbon; $\mathrm{N}$, nitrogen

${ }^{a}$ Groundwater data represent the range observed across plots, and were less deep at one of the spruce plots than at the other spruce plots on the sandy soils (between parentheses) 
six soil layers: $0-5,5-10,10-20,20-30,30-40,40-$ $50 \mathrm{~cm}$ below the soil surface. Roots were extracted from the soil cores by washing away the soil with a finemeshed $(1 \mathrm{~mm})$ sieve and by picking the roots from the remaining organic matter and soil particles. In some samples, black rhizomorphs of Armillaria species were common; they could usually but not always be distinguished from roots. Samples where these rhizomorphs were frequent and difficult to separate from fine roots were not further studied, so that sample sizes for fineroot length density, SRL, RTD and fine-root diameter varied between four and eight per stand.

Root samples were scanned and the scans analysed using WinRhizo (Regent Instruments, Canada), which measures the total root length and volume per diameter class and average diameter per soil layer. Fine $(\leq 2 \mathrm{~mm}$ diameter) and coarse ( $>2 \mathrm{~mm}$ diameter) roots were separated, oven-dried $\left(48 \mathrm{~h}\right.$ at $\left.70{ }^{\circ} \mathrm{C}\right)$ and weighed to determine root mass, and functional traits were only determined for the fine roots. Fine-root architectural traits (i.e. root mass and length) were ultimately expressed on a soil area (i.e. root mass, $\mathrm{g}_{\text {root }} \mathrm{m}^{-2}$ ) and volume (i.e. root length density, $\mathrm{cm}_{\text {root }} \mathrm{cm}^{-3}$ ) basis to allow comparison with other studies.

Regarding fine-root morphological traits, we calculated SRL (fine-root length / fine-root dry mass) and RTD (fine-root dry mass / fine-root volume) per soil layer. Because the WinRhizo software measures the mean diameter of all roots present in one sample (i.e. including the roots $>2 \mathrm{~mm}$ diameter), we could not use the software output on mean root diameter directly for fine roots. Therefore, we calculated the length-weighted mean diameter of only the fine roots separately; we calculated the root diameter for each diameter class from their root volume and length measured by WinRhizo, and averaged this for all diameter classes $\leq 2 \mathrm{~mm}$ diameter based on the proportion of the total fine-root length covered by each diameter class. Within this fine-root category, we also calculated the mean root length for the different diameter classes, relative to the total fine-root length.

Fine-root growth

Fine-root growth rates were measured using ingrowth cores. In April 2013, two root ingrowth cores were installed at each of six study trees per stand (see Study sites and design section). At $1.2 \mathrm{~m}$ (spruce) or $1.5 \mathrm{~m}$ (beech) from the stem base, we replaced a block of forest soil covered mainly with litter $(20 \times 20 \times 20 \mathrm{~cm})$ by root-free sand. After 18 months, roots were collected using a $12 \mathrm{~cm}$ diameter cylinder from the top $10 \mathrm{~cm}$ at the center of the ingrowth core. We separated fine and coarse roots and oven-dried and weighed them as described previously. Fine-root mass data were averaged per stand as an estimate of fine-root growth rate over the incubation period. Ingrowth data were expressed per soil area, per growing season (i.e. we divided the fineroot mass after two growing seasons by two).

Fine-root decomposition

Fine-root decomposition rates were measured using root litter bags. In March 2014, tree roots were sampled from one stand per species from both soil types, and fine roots were selected and air-dried. Polyester mesh bags $(10 \times$ $10 \mathrm{~cm}, 1 \mathrm{~mm}$ mesh size) were filled with $0.5 \mathrm{~g}$ of these fine roots. We buried litter bags in proximity to three of the six study trees in each of the twelve stands at 10 $15 \mathrm{~cm}$ depth, and at $1.2 \mathrm{~m}$ (spruce) or $1.5 \mathrm{~m}$ (beech) from their stem base, each bag containing the native roots only (i.e. the roots collected at the corresponding soil type). Litter bags were collected after 7 months. Four out of the 36 litter bags buried could not be retrieved. The remaining roots were carefully rinsed, dried and weighed to determine mass loss (\% of initial root mass) as an estimate of fine-root decomposition rate over the incubation period.

Mycorrhizal fungal biomass

Mycelium biomass was determined as a measure of mycorrhizal abundance because mycelia are the main fungal structure enhancing or even substituting the root absorptive area (Smith and Read 2008). We used polyester mycorrhizal mesh bags $(10 \times 6 \times 2 \mathrm{~cm}$, $38 \mu \mathrm{m}$ mesh size) that allow the ingrowth of ectomycorrhizal mycelia but not of roots (Wallander et al. 2001, 2013), which were filled with $145 \mathrm{~g}$ of quartz sand. Due to the low nutritional value of this substrate, mycorrhizal mesh bags are assumed to predominantly contain mycorrhizal fungi (Wallander et al. 2001). In April 2013, four mesh bags were buried at each of the six study trees per stand between the organic and mineral soil at a fixed distance to the stem base $(1.1 \mathrm{~m}$ for spruce and $1.4 \mathrm{~m}$ for beech). Most but not all mesh bags were retrieved in November 2013: for almost all 72 trees, 3-4 mesh bags per tree were retrieved; for one 
tree, only one bag was found. The contents of the mesh bags were pooled per tree. From this pooled sample, two subsamples of $5 \mathrm{~g}$ sand each were analysed as ecological replicates for their ergosterol content following the protocol described by Bahr et al. (2013). Ergosterol mass per tree was then averaged per stand, and served as a measure of mycorrhizal fungal biomass (Nylund and Wallander 1992).

Data analyses

Data were analyzed within the species (but see Supplementary online Table S2 for full model statistics including both species). Data were log- or square-root transformed to improve homogeneity of variance. Statistical analyses were carried out in R (R Core Team 2015, packages lme4 (Bates et al. 2015) and nlme (Pinheiro et al. 2015)). Fine-root architectural (i.e. fineroot mass and length) and morphological traits (i.e. SRL, RTD and mean fine-root diameter) and their distribution throughout the soil profile were compared between soil types using mixed models that corrected for our nested design and potential dependencies between root traits from the same stand or soil core (Zuur et al. 2009). Soil type (clay vs. sand), soil depth, and their interaction were included as fixed factors. Stand (nested within the soil types) and soil core sample (nested within the stand) were added as random factors. Because fine-root growth and decomposition, and mycelium biomass were measured at one soil depth only, they were analysed in a mixed model with soil type as the fixed factor, and stand as random factor. We compared the difference in relative root length per fine-root diameter class between the two soil types with a similar mixed-effects model, as these data were analyzed for the top soil only.

\section{Results}

Differences in fine-root architectural traits

In the stands of both species, fine-root architectural traits significantly differed between soil types. Fine-root mass and length density were more than three times higher on the sandy soil than on the clay soil over the $50 \mathrm{~cm}$ soil depth sampled (Fig. 1a, b, Supplementary online Table S3). For both species, basal area was larger, reflecting greater aboveground biomass at the stand level, on clay than on sand (Table 1). Accounting for these differences in aboveground biomass shows that in the beech forests, fine-root mass per basal area was 5.8 times higher $\left(N=12, \mathrm{~F}_{1,4}=63.33, P=0.001\right)$, and in spruce forests 5.1 times higher on sand than on clay $(N=12$, $\left.\mathrm{F}_{1,4}=78.59, P<0.001\right)$. Soil depth had a significant effect on fine-root mass and length density, and the significant interaction between soil type and soil depth indicates that the distribution of fine-root mass throughout the soil profile differed between sandy and clay soils (Fig. 2, Supplementary online Table S3). On the sandy soils, fineroot mass decreased with increasing soil depth. On the clay soils, this vertical decrease in fine-root mass was less strong for spruce, and for beech, fine-root mass was even slightly higher at 10-30 cm soil depth.

Differences in fine-root growth and decomposition

Fine-root growth rates in the ingrowth cores were more than ten times higher on the sandy soils than on the clay soils for both species (Fig. 1c, Supplementary online Table S3). This difference may have been caused by the higher initial root mass density at the sandy soils. However, fine-root mass in the ingrowth cores relative to the fine-root mass in the bulk soil was also higher at the sandy soils than at the clay soils. For beech, on the clay soils, the fine-root mass in the ingrowth cores was on average $17 \%$ of the fine-root mass in the bulk top soil (i.e. in the top $10 \mathrm{~cm}$, similar to the soil depth covered by the ingrowth cores; Table 1), whereas on the sandy soils, this percentage was $37 \%$. Spruce fine-root mass in the ingrowth cores was $19 \%$ of the mass in the bulk top soil on clay, and $49 \%$ on sand.

Fine-root decomposition in the beech stands did not differ between soil types, and after 7 months approximately $20 \%$ of the initial fine-root mass in the litter bags was lost (Fig. 1d, Supplementary online Table S3). In the spruce stands, fine-root decomposition rates were significantly lower at the sandy soils than at the clay soils, with approximately $20 \%$ on the sandy soils and $50 \%$ on the clay soils of the initial fine-root mass lost after 7 months.

\section{Differences in fine-root morphological traits}

Fine-root morphological traits differed little between soil types. Specific root length and fine-root diameter did not differ between the clay and sandy soils for either species (Fig. 1e, g, Supplementary online Table S3). Fine-root tissue density was significantly higher at the clay soil than 

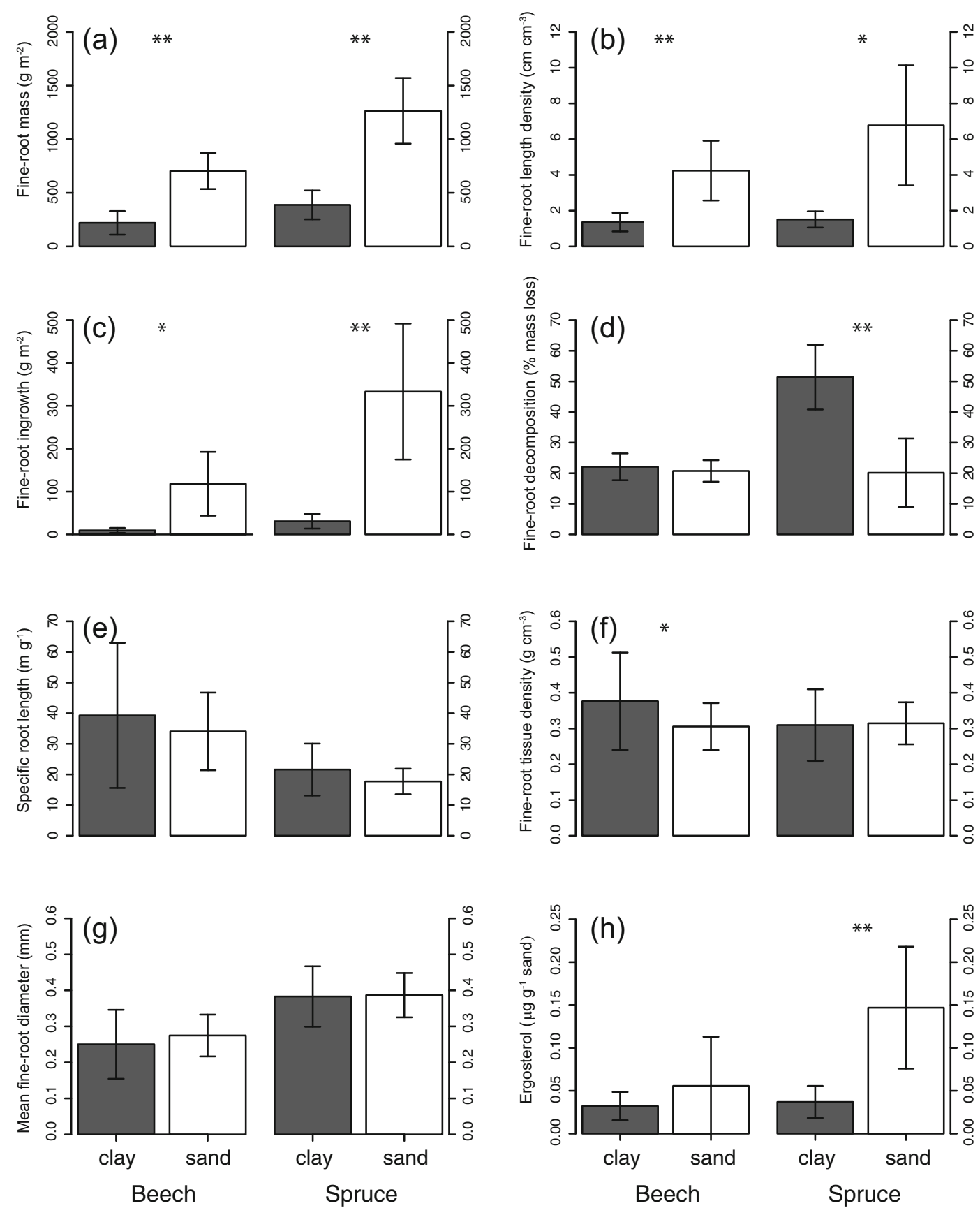

Fig. 1 Mean fine-root traits, fine-root ingrowth and decomposition, and ergosterol mass for beech and spruce forest stands on clay and sandy soils ( \pm 1 standard deviation) pooled over the soil depth. Asterisks mark significant differences between soil types within species, with $* P<0.05$, ** $P<0.01$, *** $P<0.001$. Fine-root mass and length density were summed over $50 \mathrm{~cm}$ soil depth, and then averaged per site and species. Fine-root SRL, RTD and mean fine-root diameter were averaged over the soil depth per site and

at the sandy soil for beech, but did not differ between soil types for spruce (Fig. 1f, Supplementary online
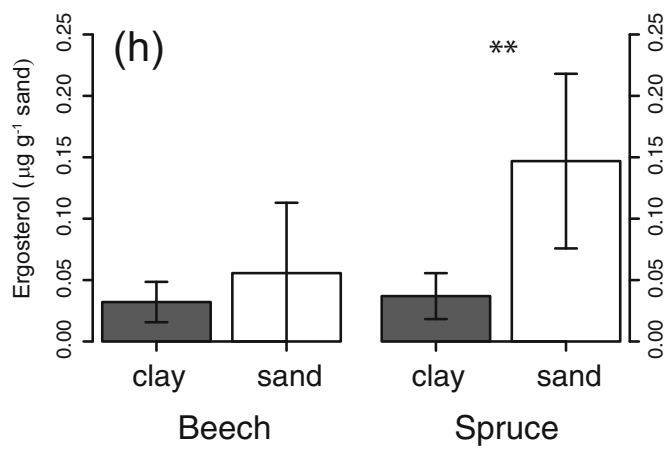

species. Ergosterol mass and fine-root decomposition rate were determined over one growing season. Fine-.root ingrowth was measured over two growing seasons but divided by two to present an annual root growth rate (see Methods section). Ergosterol mass, fine-root decomposition and fine-root growth rate were measured at one soil depth. Graphs represent raw data, whereas mixed model outputs are based on log- or square-root transformed data (Supplementary online Table S3)

Table S3). Within the fine-root category (i.e. the roots $\leq$ $2 \mathrm{~mm}$ diameter), significant shifts occurred in the root 


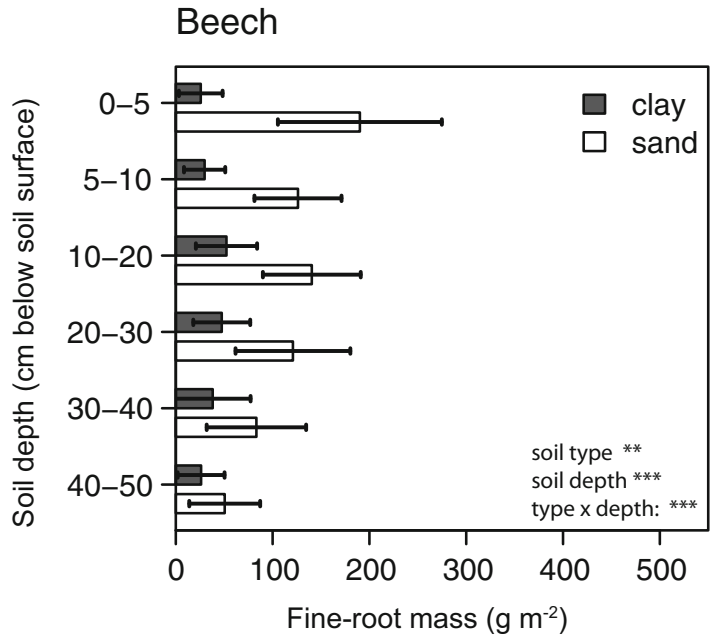

Fig. 2 Mean fine-root mass ( \pm 1 standard deviation) per soil layer throughout the soil profile $(0-50 \mathrm{~cm}$ depth) of beech and spruce forest stands on clay and sandy soils. Asterisks mark significant differences between soil types within species, with $* P<0.05$, **

length - diameter distribution between the two soil types for beech (Fig. 3). On the clay soil, the relative root length of the smallest roots $(0.1-0.3 \mathrm{~mm}$ diameter) was higher than on the sandy soil. At the sandy soil, we observed relatively more root length of the thicker beech roots (0.4-1 mm diameter). For spruce, the fine-root length distribution per diameter class did not differ between the sandy and clay soils (Fig. 3).

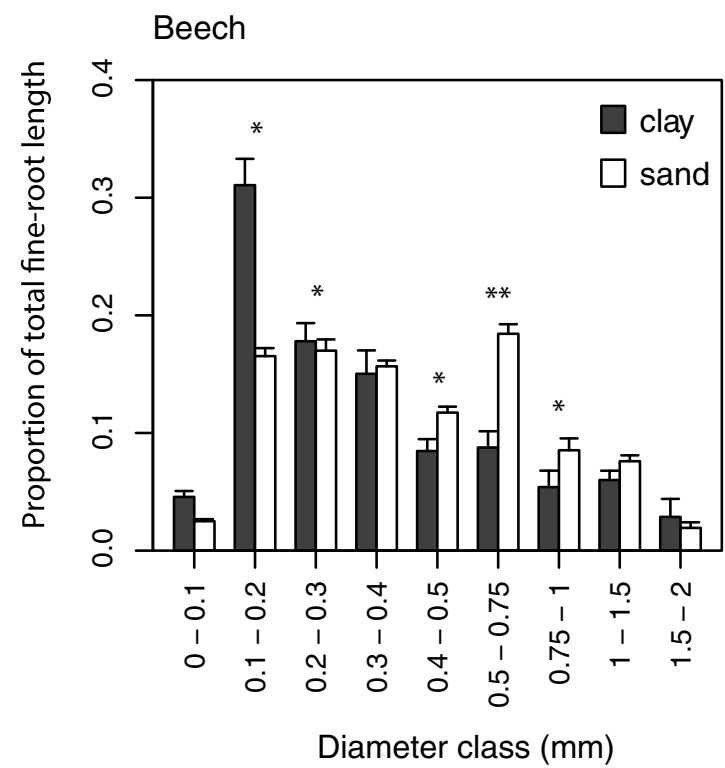

Fig. 3 Proportion fine-root length per diameter class of the total fine-root length (i.e. roots $\leq 2 \mathrm{~mm}$ diameter) for the top soil ( 0 $5 \mathrm{~cm}$ depth) of beech and spruce trees on clay and sandy soils
Spruce

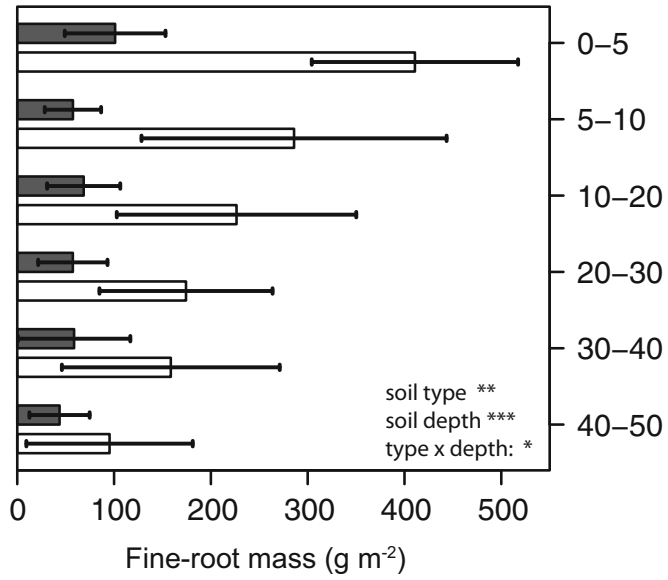

$P<0.01$, *** $P<0.001$. Graphs represent raw data, whereas mixed model outputs are based on log- or square-root transformed data (Supplementary online Table S3)

Soil depth did not affect the morphology of beech roots, as SRL, RTD and mean fine-root diameter did not change significantly with soil depth (Supplementary online Table S3, Fig. S2). For spruce, fine-root morphology did differ across the soil layers (Supplementary online Table S3). However, the variation in SRL showed no clear vertical pattern throughout the soil profile, whereas RTD slightly decreased, and mean fine-root

\section{Spruce}

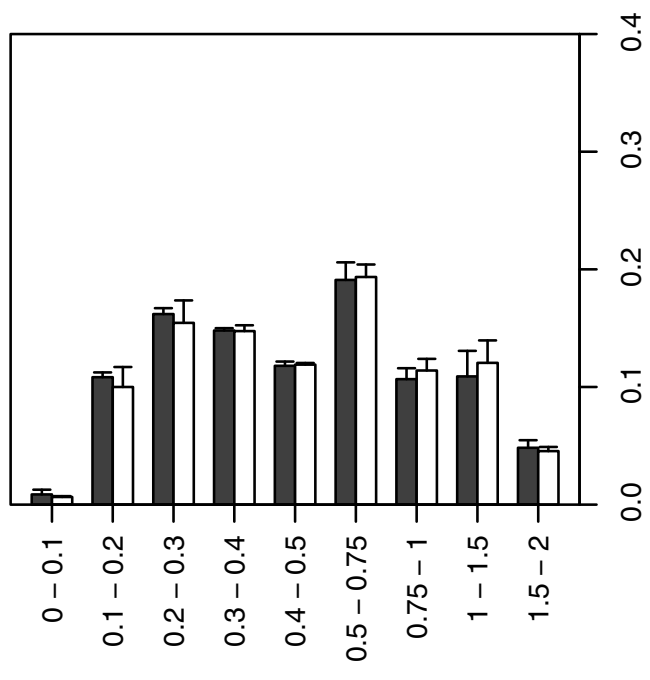

Diameter class $(\mathrm{mm})$

(means \pm 1 standard deviation). Asterisks mark significant differences between soil types within a diameter class: * $P<0.05$, ** $P<0.01$. Diameter classes of roots $>0.5 \mathrm{~mm}$ diameter vary in size 
diameter slightly increased with greater depth (Supplementary online Fig. S2).

Differences in mycorrhizal mycelium biomass

In the beech stands, mycelium biomass (represented by ergosterol mass) was on average almost two times higher in the ingrowth bags at the sandy soil than at the clay soil, but this difference was not significant (Fig. 1h, Supplementary online Table S3). In the spruce stands, mycelium biomass did differ significantly between soil types, and was four times higher at the sandy soil than at the clay soils.

\section{Discussion}

Our work demonstrates strong fine-root architectural and biotic but not morphological plasticity in beech and spruce forests on two contrasting soils. Regarding fine-root architectural plasticity (first hypothesis), fineroot mass and length density were higher on the sandy soils than on the clay soils in both beech and spruce forests. This finding may be related to the higher fineroot growth rate we observed on the sandy soils compared to clay soils (second hypothesis). Fine-root morphological traits (i.e. SRL, RTD and diameter) did not or only marginally differ between the two soil types for either species, refuting our third hypothesis. More important than plasticity in fine-root morphology, may be the mycorrhizal response to the different soil types. Indeed, mycorrhizal fungal abundance was higher on the sandy soils than on the clay soils, but these differences were only significant for spruce (fourth hypothesis). Trees on poor soils may thus rely more on changes in fine-root mass and mycorrhizal abundance than in fine-root morphology to acquire soil resources and maintain their growth rates, although this dependence may differ between species.

Fine-root mass is larger on sandy soils

In line with our first hypothesis, fine-root mass and length density were more than three times greater on our poor, sandy soils than on the rich, clay soils for both species, as also observed in other studies (Espeleta and Donovan 2002; Yuan and Chen 2010; Hertel et al. 2013). It should be noted that we cannot exclude the possibility that fine-root trait architectural differences also partly resulted from possible genetic differences (e.g. planting different beech clones on sand and clay). Furthermore, this result needs to be interpreted cautiously as differences in aboveground stand variables may confound differences in root mass between soil types. Stand basal area (i.e. the total cross-sectional area of the stems) takes both the mean stem diameter (DBH) as well as the stem density (i.e. number of trees per hectare) into account, and therefore serves as a proxy of aboveground biomass at the stand level. When we thus corrected for the smaller aboveground biomass (i.e. lower basal area, Table 1) on sand than on clay, we found five to six times larger fine-root mass on sand than on clay. This indicates that fine-root mass even more strongly increased relative to the total plant biomass and that the root: shoot ratio increased on the sandy soils compared to the clay soils. This way, trees can regulate the uptake of the most limiting resource and sustain their performance on resource-poor soils (Brouwer 1963).

Particularly on the sandy soils, fine-root mass and length density decreased with greater soil depth, measured to $50 \mathrm{~cm}$ soil depth. This vertical root distribution follows the distribution of nitrogen, phosphorus, and soil organic matter throughout the soil profile (Supplementary online Fig. S1) to increase belowground resource acquisition. At the clay soils, fine-root mass and length density differed across the soil layers as well, but did not show the strong exponential decrease that was observed on the sandy soils. At these soils, nutrients and soil organic matter were also more equally distributed between soil layers than on the sandy soils (Supplementary online Fig. S1). For both species, approximately $75 \%$ of the fine-root mass was located in the top $30 \mathrm{~cm}$ on the clay soils, versus $82 \%$ on the sandy soils. These values are higher than those reported in a meta-analysis by Jackson et al. (1996), i.e. $52 \%$ for temperate coniferous forests, and $65 \%$ for temperate deciduous forests, possibly partly because of the deeper soil layers covered by Jackson et al. (1996, i.e. more than $2 \mathrm{~m}$ soil depth in some of the studies included in the analysis) where still considerable fine-root mass may be present (Maeght et al. 2013; Pierret et al. 2016).

For beech, on both soil types, fine-root mass lies within the range of values observed across European beech forests, i.e. 116-960 $\mathrm{g}_{\text {root }} \mathrm{m}^{-2}$ reported by Finér et al. (2007). On the clay soils, beech fine-root mass was lower (i.e. 56\%), and on our sandy soils almost two times higher than the average reported by the authors (i.e. $389 \mathrm{~g}_{\text {root }} \mathrm{m}^{-2}$, Finér et al. 2007). More surprisingly, 
in our spruce stands, mean fine-root mass was 1.4 times higher on our clay soils, and 4.5 times higher on our sandy soils than the average documented by Finér et al. (2007) for spruce, i.e. $281 \mathrm{~g}_{\text {root }} \mathrm{m}^{-2}$. Furthermore, on clay, spruce fine-root biomass was within the range reported, that is $63-640 \mathrm{~g}_{\text {root }} \mathrm{m}^{-2}$, whereas on sand, it was two times higher than their maximum value (Finér et al. 2007), and we are unaware of the cause of this discrepancy.

Dutch forest soils are still relatively nitrogen-rich, as they are subjected to high nitrogen deposition rates (Waldner et al. 2014). In fact, the clay and sandy soils in our study have a low soil $\mathrm{C}: \mathrm{N}$ ratio compared to other forest soils across Europe: that is, approximately 16 in beech, and 18.5 in spruce forests (Cools et al. 2014). Yet, sandy soils are often acidified and characterized by low base cation concentrations owing to leaching (de Vries et al. 2014) and water is also less available (Table 1), which may both limit tree growth. So, even on these relatively nitrogen-rich soils, (relative) fine-root mass still strongly increased at our sandy soils to ensure sufficient belowground resource acquisition and maintain their growth rates.

\section{Differences in root dynamics driving root biomass}

Consistent with our second hypothesis, fine-root mass in the ingrowth cores was higher in the sandy soils than in the clay soils for both species. This ten-fold difference cannot merely be attributed to the differences in initial fine-root mass on the different soil types. On the clay soils, fine-root mass in the ingrowth cores was 15-20\% of the fine-root mass in the top $10 \mathrm{~cm}$ of the bulk soils, versus $35-50 \%$ on the sandy soils, suggesting faster fine-root growth on the sandy soils for both species. The large fine-root mass found on the sandy bulk soil may thus be at least partly driven by faster root growth.

The fine-root growth rates we observed differed from those documented in other studies. Fine-root growth rates in our beech stands on the clay soils were only $10 \%$ of the mean annual fine-root production rate reported in a meta-analysis by Brunner et al. (2013): 115 $\mathrm{g}_{\text {root }} \mathrm{m}^{-2} \mathrm{y}^{-1}$, and were comparable on our sandy soils. In our spruce forests, fine-root ingrowth on the clay soils was approximately half of the mean fine-root production rate reported by Brunner et al. (2013): $73 \mathrm{~g}_{\text {root }} \mathrm{m}^{-2} \mathrm{y}^{-1}$, whereas on the sandy soils it was almost five times higher. Fine-root productivity estimates may be difficult to compare across studies due to methodological differences involved (e.g. in ingrowth core substrate or incubation time). Nevertheless, the differences between root growth rates in our work and in other studies are roughly in line with the discrepancies in fine-root mass between our and other European studies, as here too, fine-root growth was much faster than predicted from earlier studies, especially for spruce.

The fine-root decomposition pattern was partly in line with our second hypothesis, where we predicted a slower decomposition on our sandy soils than on our clay soils. Beech fine-root decomposition rates did not differ between the two sites, whereas spruce fine-root decomposition was faster on the clay soils than on the sandy soil, as expected. Higher soil moisture content and soil $\mathrm{pH}$ have been found to stimulate microbial activity and litter decomposition, whereas soil $\mathrm{C}: \mathrm{N}$ ratios generally have negative effects (Solly et al. 2014). Several studies identified root rather than soil properties, such as root diameter, calcium (Ca) content, and $\mathrm{C}: \mathrm{N}$ ratios, as the main drivers of decomposition (Silver and Miya 2001; Hobbie et al. 2010; Freschet et al. 2012; Solly et al. 2014). Here, we did not measure the chemical composition of the fine roots on these study sites, but it is likely that the $\mathrm{Ca}$ content and therefore the decomposition rate of fine-root litter is higher on our Ca-rich clay soils, than on our acidic sandy soils (Silver and Miya 2001; Reich et al. 2005; Robinson 2005). The faster decomposition of spruce roots on the clay soils can thus be (partly) explained from the differences in soil and fine-root litter characteristics, but the similar decomposition rates between soil types of beech roots remain so far unexplained. We observed approximately $20 \%$ mass loss over one growing season, with the exception of spruce roots on our clay soil (approximately 50\% mass loss). Hobbie et al. (2010) observed 30\% mass loss for spruce and $40 \%$ for beech fine roots after 2 years of soil incubation.

Finally, it should be noted that fine-root growth and decomposition rates were measured in an experimental setting (ingrowth cores and litter bags, respectively), and will likely not represent actual root dynamics in the bulk soil. For example, the low fine-root mass at the clay bulk soil may also (partly) result from slow root growth due to e.g. soil compaction, that may not occur in our ingrowth cores (Kozlowski 1999). Furthermore, root turnover during the 18-month incubation may also partly explain differences in root growth between sand and clay. As spruce decomposition in our litter bags was for example faster on clay than on sand, the actual 
difference in fine-root growth rate between the two soil types may be smaller than reported. However, as both fine-root growth and decomposition were measured in different experiments, they cannot be directly related to each other. Nonetheless, as relative measures comparing the two soil types, these experimental data suggest that the differences in fine-root mass at the two soil types were to a large extent driven by differences in growth rate, and not (beech), or to a lesser degree (spruce), by differences in decomposition rates.

Fine-root morphological traits do no differ between soil types

We further hypothesized that on poor soils, SRL is higher and RTD and fine-root diameter are lower than on resource-rich soils, in order to increase resource uptake at relatively low biomass investments (Eissenstat 1992; Ryser and Lambers 1995; Eissenstat and Yanai 1997; Ostonen et al. 2007b). An opposite hypothesis follows from resource economics theory that predicts that poor soils select for species with thick fineroots of low SRL in order to retain the scarce resources acquired (i.e. a conservative strategy), whereas rich soils select for species with thin fine-roots of high SRL to efficiently and rapidly acquire soil resources (i.e. an acquisitive strategy) (Eissenstat and Yanai 1997; Aerts and Chapin 2000; Reich 2014). This trade-off between fine-root traits aimed at resource conservation and traits equipped for resource acquisition might also act within species.

We found no support for either hypothesis. Specific root length, RTD and diameter did not or only marginally differ between the sandy and clay soils. In the beech stands, the constant SRL, RTD and mean fine-root diameter throughout the soil profile also suggest that fine-root morphological traits are little affected by soil resource availability. For spruce, SRL, RTD and mean fine-root diameter differed across the soil layers sampled, but did not gradually change with increasing soil depth as could be expected based on decreasing resource availability with greater depth. These results indicate that fine-root morphology at our sites is not or hardly determined by soil resource availability. Possibly, the similar fine-root morphological traits on both soil types could be attributed to the still relatively high nutrient availability (as reflected by low soil $\mathrm{C}: \mathrm{N}$ ratios) on our forest soils compared to other European forest soils (Table 1; Cools et al. 2014). However, the large differences in fine-root mass and length density and fine-root growth rate that we observed, do indicate that trees detect and respond to the relative differences in resource availability between the sandy and clay soils studied here.

The lack of a fine-root morphological response to soil resource availability contrasts with the large number of studies that have reported consistent increases in specific leaf area (SLA) when light availability diminishes (e.g. Evans and Poorter 2001; Poorter et al. 2012; Freschet et al. 2015). Belowground, other variables such as the anchorage and transport functions of roots (Poorter and Ryser 2015), or mycorrhizal interactions (Ostonen et al. 2011; Freschet et al. 2015) may constrain the plastic response of root morphology to soil resource availability only. These constraints may also explain why our overall results do not match the resource economics theory that has been generally observed across species on leaf functional traits, but not on fine-root traits (Weemstra et al. 2016).

Similar to our results, several studies did not find plasticity in tree root morphological traits (George et al. 1997; Espeleta and Donovan 2002; Leuschner et al. 2004; Meier and Leuschner 2008; Hertel et al. 2013), whereas others did. For example, Fahey and Hughes (1994) and Ostonen et al. (2007a) found lower SRL on resource-poor compared to resource-rich soils, whereas Ostonen et al. (2007b) observed the opposite response. These results may be partly caused by the different definitions of fine roots applied across studies. For example, Fahey and Hughes (1994) focused on fine roots $<1 \mathrm{~mm}$ diameter, Ostonen et al. (2007a) studied short, mycorrhizal roots, and Ostonen et al. (2007b) reported a stronger plastic response in the $<0.5 \mathrm{~mm}$ diameter roots than in the thicker fine roots, whereas we included all roots $\leq 2 \mathrm{~mm}$ diameter. These different fineroot classifications may confound the degree of plasticity generally observed for root morphology.

Indeed, recent studies suggest that differences in root morphological plasticity may occur within the fine roots ( $\leq 2 \mathrm{~mm}$ diameter) (Poorter and Ryser 2015), because even within this category, root functions may vary (Pregitzer et al. 2002; Gu et al. 2011; McCormack et al. 2015). Our results agree with these observations. In contrast to our hypothesis but in line with resource economics theory, beech may exhibit a more acquisitive resource strategy on rich soils, by producing relatively more length of its finest roots $(0.1-0.3 \mathrm{~mm}$ diameter) that are responsible for resource acquisition. On poor 
soils, the species may adopt a more conservative strategy by producing bigger (fine) roots $(0.4-1 \mathrm{~mm}$ diameter) to enhance root lifespan and retain resources (Bardgett et al. 2014; Reich 2014). Possibly, root morphological plasticity is most relevant for the finest roots, which are assumingly most active in nutrient uptake (McCormack et al. 2015). However, these morphological adjustments may be species-specific, as for spruce, the root length distribution per diameter class was strikingly similar between sandy and clay soils. To conclude, overall fine-root morphology did not differ between our two contrasting soil types; it did change, however, within the beech fine-root category and these shifts were in line with resource economics theory.

Ectomycorrhizal fungal biomass is higher on sandy soils

As expected, mycelium biomass was higher on the sandy soils than on the clay soils, although this was statistically only significant for spruce. Compared to other studies on spruce, ergosterol mass on our clay soils was low, but on the sandy soils within the range of values reported in previous studies. Hansson et al. (2013) for example found a mean ergosterol mass of $0.13 \mu \mathrm{g} \mathrm{g}^{-1}$ sand in their 55-65 year old spruce stand in southwest Sweden, and Bahr et al. (2013) found highly variable values between 0.03 and $0.2 \mu \mathrm{g}$ ergosterol $\mathrm{g}^{-1}$ sand across 50-109 year old spruce stands in south Sweden. Other studies, however, reported much higher values, e.g. 0.25-0.5 $\mu$ g ergosterol g ${ }^{-1}$ sand (Wallander et al. 2001), up to $1 \mu \mathrm{g} \mathrm{g}^{-1}$ sand found by Wallander et al. (2011) in southern Sweden. These high values could be attributed to nitrogen deposition that is more than three times higher in the Netherlands than in south Sweden (Waldner et al. 2014) and which has a negative effect on mycelium productivity (Bahr et al. 2013). We did not find comparable studies that measured mycelium biomass based on ergosterol content in mycorrhizal mesh bags in beech forests.

In addition to our mesh bag results, we also observed more mycorrhizal types that produce mycelia on the root tips collected at our sandy soils than on our clay soil; on the clay soils, we only encountered root tips colonized by mycorrhizal types that do not produce extraradical mycelia. Together, our results thus imply that at the sandy soils, particularly in the spruce forests, more carbon was invested in mycorrhizal fungi that produce extraradical mycelia and are therefore better equipped for soil exploration and resource uptake than at the clay soils (Bahr et al. 2013). This strategy also agrees with the thicker fine roots observed on spruce, compared to beech (Supplementary online Table S2), which may be beneficial to sustain more mycorrhizal symbioses (Comas et al. 2002), and over a longer term (Bauhus and Messier 1999).

\section{Concluding remarks}

In temperate beech and spruce forests, fine-root architecture and interactions with mycorrhizal fungi, rather than root morphology, are plastic in response to soil resource availability. The lack of morphological plasticity suggests that SRL is more constrained by interacting plant and soil properties than assumed. Possibly, unexplored trade-offs with other fine-root traits (e.g. the trade-off between SRL and root lifespan (Weemstra et al. 2016)), fine-root functions (e.g. resource transport that may also occur within the $<2$-mm diameter class (Guo et al. 2008)) or alternative belowground uptake mechanisms (e.g. the impact of ectomycorrhizal fungi on fine-root diameter (Van der Heijden and Kuyper 2003)) control the degree of morphological plasticity. Consequently, an increase in fine-root mass and length density and mycorrhizal mycelium biomass may serve as alternative strategies to enhance the uptake of soil resources, and to maintain growth and survival rates on resource-poor soils, when SRL is otherwise constrained. Furthermore, fine-root plasticity may be species-specific as suggested by the morphological shifts within the fine roots observed for beech only, and the stronger mycorrhizal response observed for spruce on the two contrasting soils.

Understanding why certain fine-root traits are (not) adjusted to the soil environment requires more attention to the underlying drivers of fine-root mass and morphology, and to other mechanisms that are involved in soil resource uptake. As plasticity in fine-root mass may be more important than in morphology, further study on its underlying drivers (e.g. root growth and turnover) is needed to explain these patterns and test how general they are. Second, mycorrhizal interactions cannot be ignored in root plasticity studies as they serve as an important alternative uptake strategy, especially on poor soils, and may compensate for, and interact with, root morphological responses to resource-limitations. Third, plastic responses may occur within the fine-root category, thus calling for greater insights in the functional 
diversity of this root class. Including these insights in root research is important to enhance our understanding of tree root trait plasticity, and ultimately to determine its impacts on tree performance under different soil conditions.

Acknowledgements We are grateful to Verónica Fernández Belmonte, Purificación Gómez Ordóñez, Cristina Bernal Girona, Hans Reijnen, Jan van Walsem, Frans Möller, Jan Willem van der Paauw, Natasa Kiorapostolou, Lan Zhang, Henk van Roekel, Gerard Mekking, Ellen Wilderink, Mathieu Decuyper, Lisanne van Willigen and Carlette Nieland for their help with field and lab work. We also thank Dr. Simon Egli, Dr. Martina Peter, Prof. Håkan Wallander and Dr. Adam Bahr for their advice and support in mycorrhizal analyses, and Dr. Jos van Dam for his contribution on quantifying soil water availability. Jos Rutten, Leo Smits, Frank Klinge, Theo Gokke, Jan Floor, Rein Berends kindly facilitated and hosted our field work at the different forest stands. Finally, we thank two anonymous reviewers for their useful comments on an earlier version of this manuscript. This research was funded by the Netherlands Organisation for Scientific Research (NWO) as part of a graduate programme grant to the Graduate School Production Ecology and Resource Conservation (to M.W.), the COST Action STReESS (FP1106 to M.W.), and NWO-VIDI (grant 864.14.006 to L.M.).

Open Access This article is distributed under the terms of the Creative Commons Attribution 4.0 International License (http:// creativecommons.org/licenses/by/4.0/), which permits unrestricted use, distribution, and reproduction in any medium, provided you give appropriate credit to the original author(s) and the source, provide a link to the Creative Commons license, and indicate if changes were made.

\section{References}

Aerts R, Chapin F (2000) The mineral nutrition of wild plants revisited: a re-evaluation of processes and patterns. Adv Ecol Res 30:1-67

Bahr A, Ellström M, Akselsson C et al (2013) Growth of ectomycorrhizal fungal mycelium along a Norway spruce forest nitrogen deposition gradient and its effect on nitrogen leakage. Soil Biol Biochem 59:38-48

Bardgett RD, Mommer L, de Vries FT (2014) Going underground: root traits as drivers of ecosystem processes. Trends Ecol Evol 29:692-699

Bates D, Maechler M, Bolker B, Walker S (2015) Fitting linear mixed-effects models using lme4. J Stat Softw 67:1-45

Bauhus J, Messier C (1999) Soil exploitation strategies of fine roots in different tree species of the southern boreal forest of eastern Canada. Can J For Res 29:260-273

Bradshaw A (1965) Evolutionary significance of phenotypic plasticity in plants. Adv Genet 13:115-155

Brouwer R (1963) Some aspects of the equilibrium between overground and underground plant parts. Jaarb van het Inst Voor Biol en Scheikd Onderz aan Landbouwgewassen 31-39
Brunner I, Bakker MR, Björk RG et al (2013) Fine-root turnover rates of European forests revisited: an analysis of data from sequential coring and ingrowth cores. Plant Soil 362:357372

Comas LH, Bouma TJ, Eissenstat DM (2002) Linking root traits to potential growth rate in six temperate tree species. Oecologia 132:34-43

Cools N, Vesterdal L, De Vos B et al (2014) Tree species is the major factor explaining $\mathrm{C}: \mathrm{N}$ ratios in European forest soils. For Ecol Manag 311:3-16

Craine J (2009) Resource strategies of wild plants. Princeton University Press, Princeton

de Vries W, Dobbertin MH, Solberg S et al (2014) Impacts of acid deposition, ozone exposure and weather conditions on forest ecosystems in Europe: an overview. Plant Soil 380:1-45

Eissenstat DM (1992) Costs and benefits of constructing roots of small diameter. J Plant Nutr 15:763-782

Eissenstat D, Yanai R (1997) The ecology of root lifespan. Adv Ecol Res 27:1-59

Espeleta JF, Donovan LA (2002) Fine root demography and morphology in response to soil resources availability among xeric and mesic sandhill tree species. Funct Ecol 16:113-121

Evans J, Poorter H (2001) Photosynthetic acclimation of plants to growth irradiance: the relative importance of specific leaf area and nitrogen partitioning in maximizing carbon gain. Plant Cell Environ 24:755-767

Fahey TJ, Hughes JW (1994) Fine root dynamics in a Northern Hardwood Forest Ecosystem, Hubbard Brook Experimental Forest, NH. J Ecol 82:533-548

Finér L, Helmisaari H-S, Lõhmus K et al (2007) Variation in fine root biomass of three European tree species: beech (Fagus sylvatica L.), Norway spruce (Picea abies L. Karst.), and Scots pine (Pinus sylvestris L.). Plant Biosyst Int J Deal Asp Plant Biol 141:394-405

Freschet GT, Aerts R, Cornelissen JHC (2012) A plant economics spectrum of litter decomposability. Funct Ecol 26:56-65

Freschet GT, Swart EM, Cornelissen JHC (2015) Integrated plant phenotypic responses to contrasting above- and belowground resources: key roles of specific leaf area and root mass fraction. New Phytol 206:1247-1260

Gaul D, Hertel D, Borken W et al (2008) Effects of experimental drought on the fine root system of mature Norway spruce. For Ecol Manag 256:1151-1159

George E, Seith B, Schaeffer C, Marschner H (1997) Responses of Picea, Pinus and Pseudotsuga roots to heterogeneous nutrient distribution in soil. Tree Physiol 17:39-45

Grime JP (1977) Evidence for the existence of three primary strategies in plants and its relevance to ecological and evolutionary theory. Am Nat 111:1169-1194

$\mathrm{Gu}$ J, Yu S, Sun Y et al (2011) Influence of root structure on root survivorship: an analysis of 18 tree species using a minirhizotron method. Ecol Res 26:755-762

Guo D, Xia M, Wei X et al (2008) Anatomical traits associated with absorption and mycorrhizal colonization are linked to root branch order in twenty-three Chinese temperate tree species. New Phytol 180:673-683

Hansson K, Helmisaari H-S, Sah SP, Lange H (2013) Fine root production and turnover of tree and understorey vegetation in Scots pine, silver birch and Norway spruce stands in SW Sweden. For Ecol Manag 309:58-65 
Hertel D, Strecker T, Mueller-Haubold H, Leuschner C (2013) Fine root biomass and dynamics in beech forests across a precipitation gradient - is optimal resource partitioning theory applicable to water-limited mature trees? J Ecol 101:1-18

Hobbie SE, Oleksyn J, Eissenstat DM, Reich PB (2010) Fine root decomposition rates do not mirror those of leaf litter among temperate tree species. Oecologia 162:505-513

Högberg MN, Baath E, Nordgren A et al (2003) Contrasting effects of nitrogen availability on plant carbon supply to mycorrhizal fungi and saprotrophs - A hypothesis based on field observations in boreal forest. New Phytol 160:225-238

Holdaway RJ, Richardson SJ, Dickie IA et al (2011) Species- and community-level patterns in fine root traits along a 120000 year soil chronosequence in temperate rain forest. J Ecol 99: 954-963

Jackson RB, Canadell J, Ehleringer JR et al (1996) A global analysis of root distributions for terrestrial biomes. Oecologia 108:389-411

Kjøller R, Nilsson L-O, Hansen K et al (2012) Dramatic changes in ectomycorrhizal community composition, root tip abundance and mycelial production along a stand-scale nitrogen deposition gradient. New Phytol 194:278-286

KNMI (2009) Nader verklaard: Zomer in Flevoland. http://www. knmi.nl/cms/content/58105/zomer_in_flevoland. Accessed 1 Feb 2012

Kozlowski TT (1999) Soil compaction and growth of woody plants. Scand J For Res 14:596-619

Leuschner C, Hertel D (2003) Fine root biomass of temperate forests in relation to soil acidity and fertility, climate, age and species. Prog Bot 64:405-438

Leuschner C, Hertel D, Schmid I et al (2004) Stand fine root biomass and fine root morphology in old-growth beech forests as a function of precipitation and soil fertility. Plant Soil 258:43-56

Maeght J-L, Rewald B, Pierret A (2013) How to study deep rootsand why it matters. Front Plant Sci 4:299

McCormack ML, Adams TS, Smithwick EH, Eissenstat DM (2012) Predicting fine root lifespan from plant functional traits in temperate trees. New Phytol 195:823-831

McCormack ML, Dickie IA, Eissenstat DM et al (2015) Redefining fine roots improves understanding of belowground contributions to terrestrial biosphere processes. New Phytol 207:505-518

Meier IC, Leuschner C (2008) Genotypic variation and phenotypic plasticity in the drought response of fine roots of European beech. Tree Physiol 28:297-309

Nilsson LO, Giesler R, Bååth E, Wallander H (2005) Growth and biomass of mycorrhizal mycelia in coniferous forests along short natural nutrient gradients. New Phytol 165:613-622

Nylund J-E, Wallander H (1992) Ergosterol analysis as a means of quantifying mycorrhizal biomass. In: Norris JR, Read DJ, Varma AK (eds) Methods microbiol. Academic, London, pp $77-88$

Ostonen I, Lõhmus K, Lasn R (1999) The role of soil conditions in fine root ecomorphology in Norway spruce (Picea abies (L.) Karst.). Plant Soil 208:283-292

Ostonen I, Lõhmus K, Helmisaari H et al (2007a) Fine root morphological adaptations in Scots pine, Norway spruce and silver birch along a latitudinal gradient in boreal forests. Tree Physiol 27:1627-1634
Ostonen I, Püttsepp Ü, Biel C et al (2007b) Specific root length as an indicator of environmental change. Plant Biosyst Int J Deal Asp Plant Biol 141:426-442

Ostonen I, Helmisaari H-S, Borken W et al (2011) Fine root foraging strategies in Norway spruce forests across a European climate gradient. Glob Chang Biol 17:3620-3632

Pérez-Ramos IM, Roumet C, Cruz P et al (2012) Evidence for a "plant community economics spectrum" driven by nutrient and water limitations in a Mediterranean rangeland of southern France. J Ecol 100:1315-1327

Pierret A, Maeght J-L, Clément C et al (2016) Understanding deep roots and their functions in ecosystems: an advocacy for more unconventional research. Ann Bot 118:621-635

Pinheiro J, Bates D, DebRoy S et al (2015) nlme: linear and nonlinear mixed effects models. R Package Version 3:1-103

Poorter H, Ryser P (2015) The limits to leaf and root plasticity: what is so special about specific root length? New Phytol 206:1188-1190

Poorter H, Niklas KJ, Reich PB et al (2012) Biomass allocation to leaves, stems and roots: meta-analyses of interspecific variation and environmental control. New Phytol 193:30-50

Pregitzer KS, DeForest JL, Burton AJ et al (2002) Fine root architecture of nine North American trees. Ecol Monogr 72: 293-309

Prieto I, Roumet C, Cardinael R et al (2015) Root functional parameters along a land-use gradient: evidence of a community-level economics spectrum. J Ecol 103:361-373

R Core Team (2015) R: a language and environment for statistical computing. R Foundation for Statistical Computing, Vienna, Austria. URL http://www.R-project.org/

Reich P (2014) The world-wide "fast-slow" plant economics spectrum: a traits manifesto. J Ecol 102:275-301

Reich PB, Oleksyn J, Modrzynski J et al (2005) Linking litter calcium, earthworms and soil properties: a common garden test with 14 tree species. Ecol Lett 8:811-818

Robinson D (2005) Integrated root responses to variations in nutrient supply. In: BassiriRad H (ed) Nutr. Acquis. by Plants. An Ecol. Perspect. Springer Berlin Heidelberg, Berlin, pp 43-61

Ryser P, Eek L (2000) Consequences of phenotypic plasticity vs. interspecific differences in leaf and root traits for acquisition of aboveground and belowground resources. Am J Bot 87: 402-411

Ryser P, Lambers H (1995) Root and leaf attributes accounting for the performance of fast- and slow-growing grasses at different nutrient supply. Plant Soil 170:251-265

Silver WL, Miya RK (2001) Global patterns in root decomposition: comparisons of climate and litter quality effects. Oecologia 129:407-419

Smith SE, Read DJ (2008) Mycorrhizal symbiosis, 3rd edn. Academic, London

Solly EF, Schöning I, Boch S et al (2014) Factors controlling decomposition rates of fine root litter in temperate forests and grasslands. Plant Soil 382:203-218

Sterck FJ, Duursma RA, Pearcy RW et al (2013) Plasticity influencing the light compensation point offsets the specialization for light niches across shrub species in a tropical forest understorey. J Ecol 101:971-980

Valladares F, Gianoli E, Gómez JM (2007) Ecological limits to plant phenotypic plasticity. New Phytol 176: 749-763 
Valverde-Barrantes OJ, Raich JW, Russell AE (2007) Fine-root mass, growth and nitrogen content for six tropical tree species. Plant Soil 290:357-370

Van der Heijden EW, Kuyper TW (2003) Ecological strategies of ectomycorrhizal fungi of Salix repens: root manipulation versus root replacement. Oikos 103:668-680

Wahl S, Ryser P (2000) Root tissue structure is linked to ecological strategies of grasses. New Phytol 148:459-471

Waldner P, Marchetto A, Thimonier A et al (2014) Detection of temporal trends in atmospheric deposition of inorganic nitrogen and sulphate to forests in Europe. Atmos Environ 95: 363-374

Wallander H, Nilsson L, Hagerberg D, Baath E (2001) Estimation of the biomass and seasonal growth of external mycelium of ectomycorrhizal fungi in the field. New Phytol 151:753-760

Wallander H, Ekblad A, Bergh J (2011) Growth and carbon sequestration by ectomycorrhizal fungi in intensively fertilized Norway spruce forests. For Ecol Manag 262:999-1007
Wallander H, Ekblad A, Godbold DL et al (2013) Evaluation of methods to estimate production, biomass and turnover of ectomycorrhizal mycelium in forests soils-A review. Soil Biol Biochem 57:1034-1047

Weemstra M, Mommer L, Visser EJW et al (2016) Towards a multidimensional root trait framework: a tree root review. New Phytol 211:1159-1169

Withington J, Reich P, Oleksyn J, Eissenstat D (2006) Comparisons of structure and life span in roots and leaves among temperate trees. Ecol Monogr 76:381-397

Yuan ZY, Chen H (2010) Fine root biomass, production, turnover rates, and nutrient contents in boreal forest ecosystems in relation to species, climate, fertility, and stand age: literature review and meta-analyses. CRC Crit Rev Plant Sci 29:204 221

Zuur AF, Ieno EN, Walker N et al (2009) Mixed effects models and extensions in ecology with R. Springer New York, New York 